\title{
Glutamate Induces the Production of Reactive Oxygen Species in Cultured Forebrain Neurons Following NMDA Receptor Activation
}

\author{
lan J. Reynolds ${ }^{1}$ and Teresa G. Hastings ${ }^{2}$ \\ Departments of ${ }^{1}$ Pharmacology and ${ }^{2}$ Neuroscience, University of Pittsburgh, Pittsburgh, Pennsylvania 15261
}

\begin{abstract}
Using the fluorescent dye $2^{\prime}, 7^{\prime}$-dichlorodihydrofluorescein (DCF- $\mathrm{H}_{2}$ ) we investigated the role of glutamate in the production of reactive oxygen species (ROS) in cultured neurons from fetal rat forebrain. The addition of an excitotoxic concentration of glutamate $(100 \mu \mathrm{m})$ produced a generalized decrease in cellular DCF fluorescence accompanied by local areas of increased fluorescence around the margins of the cell body that could be observed within 2-4 min of glutamate exposure. Increases in fluorescence were dependent on NMDA receptor activation and $\mathrm{Ca}^{2+}$ entry and were blocked by the mitochondrial proton ionophore carbonyl cyanide $p$-trifluoromethoxyphenylhydrazone (FCCP). Additional studies suggested that the generalized decrease in fluorescence was due to intracellular acidification. These studies suggest a critical role for mitochondria in the production of ROS in association with glutamate excitotoxicity, and additionally demonstrate the feasibility of measuring the production of ROS at the level of the single cell.

[Key words: dichlorofluorescein, excitotoxicity, fluorescence microscopy, intracellular $\mathrm{Ca}^{2+}$, intracellular $\mathrm{pH}, \mathrm{mi}$ tochondria, NMDA receptor, reactive oxygen species]
\end{abstract}

The excitatory neurotransmitter glutamate is believed to play a critical role in the neuronal injury that results from cerebral ischemia or head trauma. Following either of these insults the concentration of extracellular glutamate is elevated, and neurons later die (Rothman and Olney, 1987; Choi, 1988; Faden et al., 1989; Benveniste, 1991). The processes that occur in between the increased availability of glutamate and the death of neurons are not well understood. Glutamate receptor antagonists can block a portion of neuronal injury, thus suggesting that glutamate receptor activation is an important part of the degenerative process (Rothman and Olney, 1987; Choi, 1988; Faden et al., 1989; Benveniste, 1991). Many other processes have been associated with cerebral ischemia and head trauma in vivo, including an increase in the accumulation of cellular $\mathrm{Ca}^{2}$, acidosis, hyperkalemia, activation of proteases, synthesis of nitric oxide, and production of reactive oxygen species (ROS), that also may contribute to neuronal injury (Siesjo and Wieloch,

\footnotetext{
Received June 27, 1994; revised Nov. 15, 1994; accepted Nov. 22, 1994.

We thank Kristi Rothermund for cell culture preparation, Kari Hoyt, and Sunita Rajdev for advice and assistance with intracellular pH recording, and Dr. Stan Thayer for helpful discussions. This work was supported by a Grantin-Aid from the American Heart Association (I.J.R.) and USPHS Grants NS09076 and NS19608 (T.G.H.). I.J.R. is an Established Investigator of the American Heart Association.

Correspondence should be addressed to Ian J. Reynolds, Department of Pharmacology, University of Pittsburgh, E1354 Biomedical Science Tower, Pittsburgh, PA 15261

Copyright C 1995 Society for Neuroscience $0270-6474 / 95 / 153318-10 \$ 05.00 / 0$
}

1985; Wieloch, 1985; Hall and Braughler, 1989; Choi, 1990; Dawson et al., 1991; Beal, 1992; Halliwell, 1992; Frandsen and Schousboe, 1993; Tombaugh and Sapolsky, 1993). However, the precise contribution of each of these factors is unclear, in part because of the difficulty of establishing the temporal sequence of events that occur after the initial insult.

Cell culture models of excitotoxicity have provided important insights into the processes involved in cell death, and two mechanisms that may contribute to the cytotoxic effects of glutamate have been identified. One mechanism requires activation of NMDA receptors and intracellular $\mathrm{Ca}^{2+}$ accumulation. Intense stimulation of NMDA receptors generated by only $5 \mathrm{~min}$ of exposure to an excitotoxin; cell death is expressed within 12$24 \mathrm{hr}$ (Choi, 1987; Choi et al., 1987). The second mechanism is associated with non-NMDA receptor-mediated excitotoxicity and takes more than $1 \mathrm{hr}$ of exposure to produce a lethal stimulus. This type of excitotoxicity is more critically affected by factors that alter the osmotic status of neurons, and can be prevented by $\mathrm{Na}^{+}$or $\mathrm{Cl}^{-}$removal (Rothman, 1985; Choi, 1987; Rothman et al., 1987).

Evidence obtained through cell culture models and in vivo experiments indicate that ROS, such as superoxide anion, hydroxyl radical, and hydrogen peroxide, are produced during the process of neuronal death (Coyle and Puttfarcken, 1993). The application of NMDA elicits the generation of ROS from cerebellar granule cells (Lafon-Cazal et al., 1993). In addition, antioxidants such as the 21-aminosteroid tirilizad, can partially protect cultured neurons from NMDA receptor-mediated cell injury (Monyer et al., 1990). In vivo studies examining the consequences of ROS overproduction have reported increased lipid peroxides and other indices of oxidation (Hall and Braughler, 1989; Halliwell, 1992; Haddad and Jiang, 1993). However, these studies have not established whether ROS production occurs early or late in the sequence of events surrounding neuronal death. This is a critical issue in evaluating the therapeutic potential of antioxidants that may be neuroprotective. Moreover, although several mechanisms of glutamate-induced ROS production have been proposed, including the metabolism of arachidonic acid (Lafon-Cazal et al., 1993) and the $\mathrm{Ca}^{2+}$-activated enzymatic conversion of xanthine dehydrogenase to xanthine oxidase (Dykens et al., 1987), the mechanism by which glutamate can induce the production of ROS remains unclear.

The goal of the present study was to investigate the characteristics of glutamate-induced ROS production in cultured forebrain neurons. We have used the dye $2^{\prime}, 7^{\prime}$-dichlorodihydrofluorescein (DCF- $\mathrm{H}_{2}$, Cathcart et al., 1983; LeBel et al., 1992) to follow ROS production in cultured neurons by monitoring the increase in fluorescence associated with the oxidation of DCF- 
Table 1. Effects of drugs on the increase in dichlorofluorescein fluorescence induced by glutamate

\begin{tabular}{|c|c|c|c|c|c|c|}
\hline \multirow[b]{2}{*}{ Drug $(\mu \mathrm{M})$} & \multicolumn{3}{|c|}{ Drug treated } & \multicolumn{3}{|c|}{ Glutamate alone } \\
\hline & Positive & Total & $\%$ & Positive & Total & $\%$ \\
\hline Glutamate (100) & & & & 255 & 439 & 58.1 \\
\hline Glutamate (3) & 11 & 52 & 21.2 & 28 & 45 & 62.2 \\
\hline Dizocilpine (1) & 0 & 41 & 0 & 21 & 37 & 56.8 \\
\hline $\operatorname{CNQX}(50)^{a}$ & 14 & 24 & 58.3 & 21 & 37 & 56.8 \\
\hline NMDA $(100)^{\prime \prime}$ & 8 & 35 & 22.9 & 21 & 34 & 61.8 \\
\hline Kainate $(100)^{n}$ & 0 & 31 & 0 & 21 & 34 & 61.8 \\
\hline $\mathrm{Ca}^{2}$ free & 1 & 40 & 2.5 & 17 & 35 & 48.6 \\
\hline $\mathrm{BPB}(10)$ & 29 & 62 & 46.8 & 33 & 51 & 64.7 \\
\hline Indomethacin $(10)+$ NDGA $(10)$ & 23 & 52 & 44.2 & 56 & 77 & 72.7 \\
\hline FCCP $(5)$ & 0 & 63 & 0 & 40 & 70 & 57.1 \\
\hline Nitroarginine (100) & 28 & 36 & 77.8 & 19 & 50 & 38.0 \\
\hline
\end{tabular}

Data are given for the number of cells scored as positive by a blinded observer as described in Materials and Methods and are compared to the number of cells scored as positive trom fields treated with $100 \mu \mathrm{M}$ glutamate and $10 \mu \mathrm{M}$ glycine alone on the same experimental day. All of the drug treatments were performed in cells treated with $100 \mu \mathrm{M}$ glutamate and $10 \mu \mathrm{M}$ glycine except NMDA, kainate, and the lower glutamate concentration.

${ }^{u, b}$ Experiments were performed on the same experimental day so the control data are shared.

$\mathrm{H}_{2}$ to DCF. We have demonstrated that excitotoxic concentrations of glutamate rapidly produce ROS by a process that involves $\mathrm{Ca}^{2+}$ entry through NMDA receptors, suggesting that ROS production is an early event in glutamate-induced neuronal injury. Additional evidence suggests that ROS production occurs as a result of $\mathrm{Ca}^{2+}$ uptake into mitochondria.

\section{Materials and Methods}

Cell culture. Neurons were cultured from e17 embryos obtained from Sprague-Dawley rats (Zivic-Miller, Zelienople, PA). Cortical lobes were removed and placed in $\mathrm{Ca}^{2+}-\mathrm{Mg}^{2+}$ free minimal essential medium, dissected free of connective tissue, chopped, and then incubated in $0.025 \%$ trypsin (GIBCO, Grand Island, NY) for 30 min at $37^{\circ} \mathrm{C}$. After agitation the superficial layer of cells were removed, counted using trypan blue to identify non-viable cells, and then diluted to the appropriate volume in Dulbecco's Modificd Eagles Medium (DMEM) containing $10 \%$ fetal bovine serum, and $100 \mathrm{U} / \mathrm{ml}$ penicillin and $100 \mu \mathrm{g} /$ $\mathrm{ml}$ streptomycin. Cells were plated at a density of 300,000 cells per well in six-well plates. Each well contained one $31 \mathrm{~mm} \# 1$ glass coverslip, previously coated with $10 \mu \mathrm{g} / \mathrm{ml}$ poly-L-lysine. After $24 \mathrm{hr}$ the media was removed and replaced with media containing $10 \%$ heatinactivated horse serum in place of the fetal bovine serum. The coverslips were then inverted and the plates returned to the incubator until use. Cells were maintained under $95 \%$ air, $5 \% \mathrm{CO}_{2}$ at $37^{\circ} \mathrm{C}$ until use (usually 20-28 d).

Fluorescence microscopy. On the day of experimentation cells were placed in a HEPES-buffered salt solution (HBSS) of the following composition (mM): $\mathrm{NaCl}, 137 ; \mathrm{KCl}, 5 ; \mathrm{MgSO}_{4}, 0.9 ; \mathrm{CaCl}_{2}, 1.4 ; \mathrm{NaHCO}_{3}$, 3; $\mathrm{Na}_{2} \mathrm{HPO}_{4}, 0.6 ; \mathrm{KH}_{2} \mathrm{PO}_{4}, 0.4$; glucose, 5.6; and HEPES, 20; adjusted to $\mathrm{pH} 7.4$ with $\mathrm{NaOH}$. Coverslips were then inverted (cell layer now facing up) and incubated in $10 \mu \mathrm{M}$ DCF- $\mathrm{H}_{2}$ as the diacetate in HBSS supplemented with $5 \mathrm{mg} / \mathrm{ml}$ bovine serum albumin for $15 \mathrm{~min}$ at $37^{\circ} \mathrm{C}$. After rinsing with HBSS, the coverslips were then mounted on the stage of an ACAS 570c imaging system (Meridian Instruments, Okemos, MI). Cells were illuminated with the $488 \mathrm{~nm}$ line of an argon laser that was operating at $200 \mathrm{~mW}$ and had been attenuated to $3 \%$ of starting values using the acousto-optical modulator of this system, and additionally by passage through a $7 \%$ neutral density filter, such that approximately $0.2 \%$ of the initial laser power illuminated the sample. Cells were illuminated and fluorescence signal collected using a $40 \times$ phase contrast lens. We used a $80 \mu \mathrm{m}$ pinhole throughout these experiments, which should result in an optical slice of about $2.5 \mu \mathrm{m}$ through the middle of the neurons, which averaged about $20 \mu \mathrm{m}$ in diameter. We did not use an emission filter in these experiments. However, under the recording conditions used autofluorescence was undetectable.

We typically recorded fluorescence from one field of cells per cov- erslip that was $180 \mu \mathrm{m}^{2}$ and contained 514 neurons, and one image was acquired per minute. After acquiring 2 images of baseline fluorescence levels drugs were applied as appropriate, and 10 additional images were obtained. When inhibitors were used they were incubated with cells for 2 scans prior to the addition of agonists, such that a total of 14 scans were acquired. Drug solutions were changed by aspiration and replacement between image acquisitions. The incomplete exchange achieved using this approach probably means that the drug concentrations described are slight overestimates $(<5 \%)$. On each experimental day we also measured the effects of adding $\mathrm{H}_{2} \mathrm{O}_{2}(30 \mathrm{~mm})$ or the effect of buffer change as controls.

Images obtained with $\mathrm{BCECF}$ were measured at a single wavelength $(488 \mathrm{~nm})$ using identical optical parameters to those for DCF- $\mathrm{H}_{2}$ after cells had been loaded with BCECF-AM $(5 \mu \mathrm{M})$ for $15 \mathrm{~min}$. Ratiometric microspectrofluorimetry with BCECF was performed on an instrument previously described for intracellular $\mathrm{Ca}^{2+}$ studies (Reynolds and Aizenman, 1992) and modified by the use of 440 and $490 \mathrm{~nm}$ excitation filters, a $530 \mathrm{~nm}$ emission filter, and a Nikon ND16 neutral density filter. Data from these experiments is presented as a ratio of fluorescence recorded at the two wavelengths. We did not attempt to calibrate either signal.

Data analysis. We took two approaches to analyzing this data. We quantified the total cellular fluorescence and expressed this as a fraction of the starting value. Basically, this approach averages the increase in DCF signal due to oxidation with the decrease due to intracellular acidification and, following glutamate addition, generally resulted in an overall decrease in cellular fluorescence due to the more widespread nature of the acidification compared to the oxidation response. To quantify the oxidation response an observer blinded to the treatment condition (I.J.R.) scored each cell as a responder if it showed a local increase in fluorescence above starting values that was present in two or more consecutive images after the addition of glutamate. The responding cells were expressed as a fraction of the total number of cells tested. For each condition described at least four coverslips were used from at least two separate culture preparations. We noticed some variability in the fraction of cells that were scored as responders between culture preparations, so each set of experimental manipulations is accompanied by a similar number of observations made on cells treated with glutamate alone (Table 1).

Materials. DCF- $\mathrm{H}_{2}$ as the diacetate and BCECF-AM were purchased from Molecular Probes (Eugene, OR). DCF- $\mathrm{H}_{2}$ was dissolved in methanol at $4 \mathrm{~mm}$ and kept under nitrogen until use. Stock solutions were made on a daily basis. All experiments were performed using a single batch of DCF- $\mathrm{H}_{2}$. Cell culture solutions were obtained from GIBCO (Grand Island, NY). Dizocilpine was a generous gift of Merck Sharp and Dohme (West Point, PA). CNQX was obtained from Research Bio- 

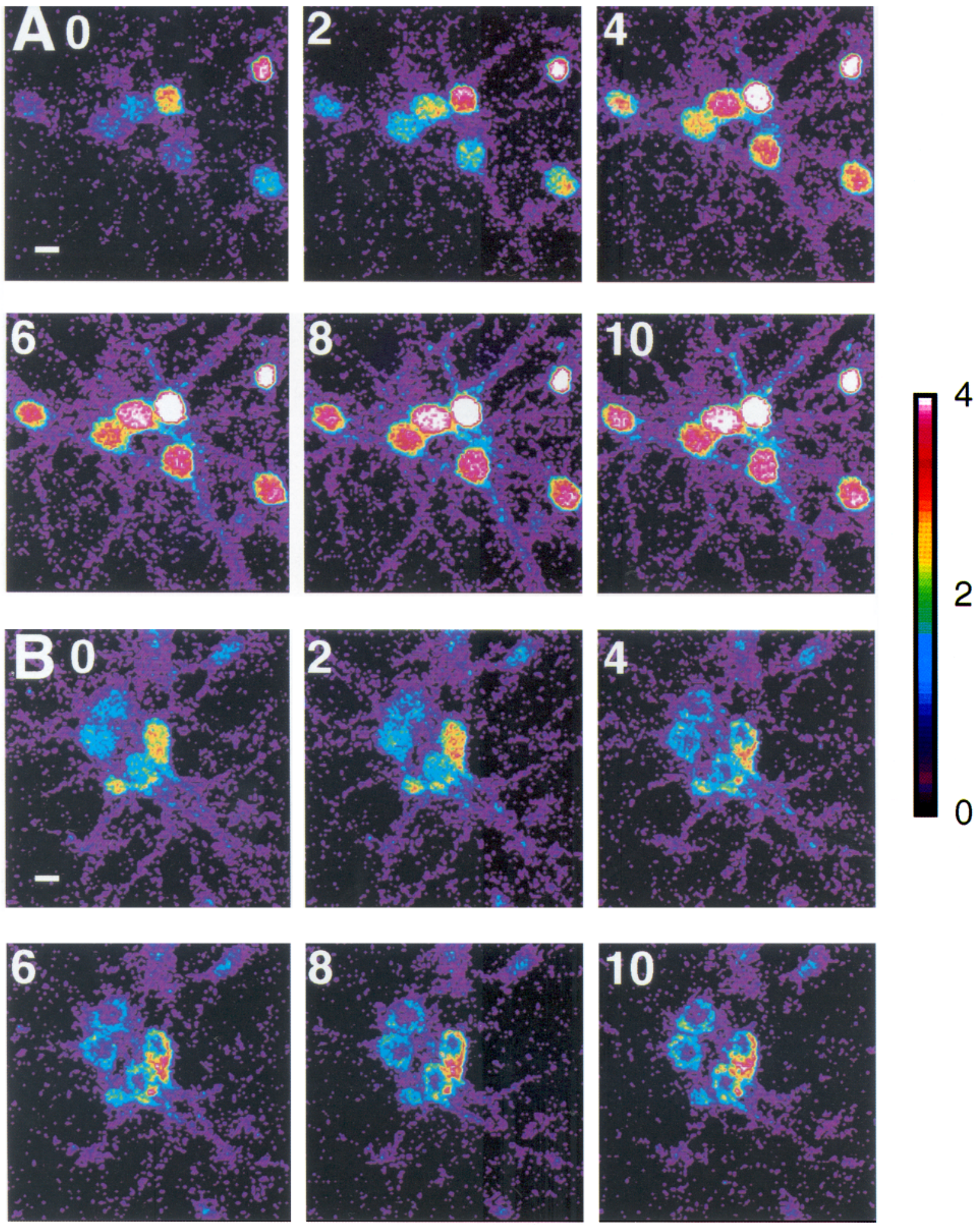

Figure 1. Localization of changes of DCF fluorescence in cultured neurons. A, Effects of $\mathrm{H}_{2} \mathrm{O}_{2}$ on DCF fluorescence. Cells were treated with 30 $\mathrm{mM} \mathrm{H}_{2} \mathrm{O}_{2}$ just before the second image was obtained. The numbers represent the time $(\mathrm{min})$ after the start of the experiment. Images were obtained every minute; alternate images are shown. $B$, Effects of glutamate. The experiment was performed in the same way as $A$ except that $100 \mu \mathrm{M}$ glutamate and $10 \mu \mathrm{M}$ glycine were added prior to the second scan. The experiments depicted in $A$ and $B$ were performed on at least 20 additional coverslips. $C$ and $D$, Phase contrast photomicrographs corresponding to the field of cells used in $A$ and $B$, respectively. Scale bars, $10 \mu \mathrm{m}$. 


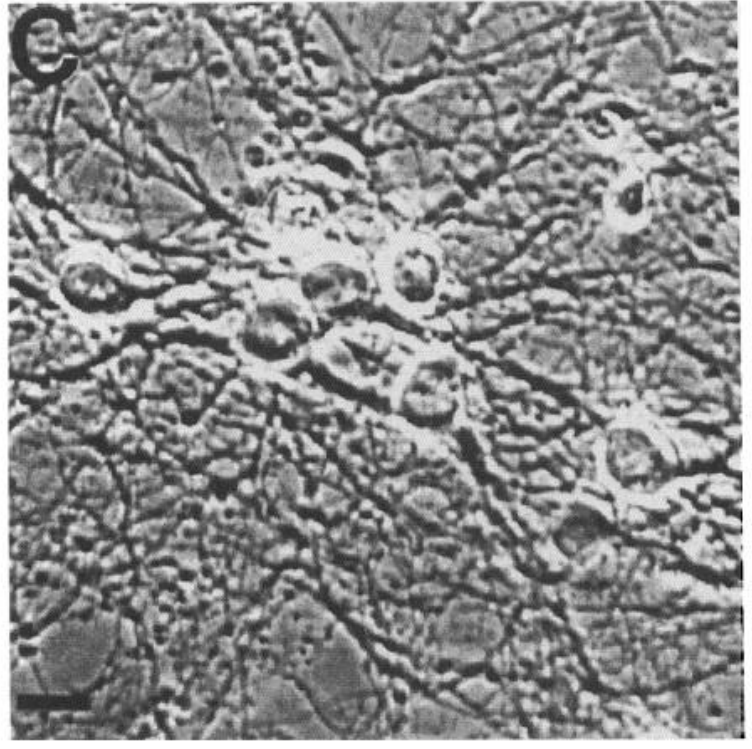

Figure 1. Continued.

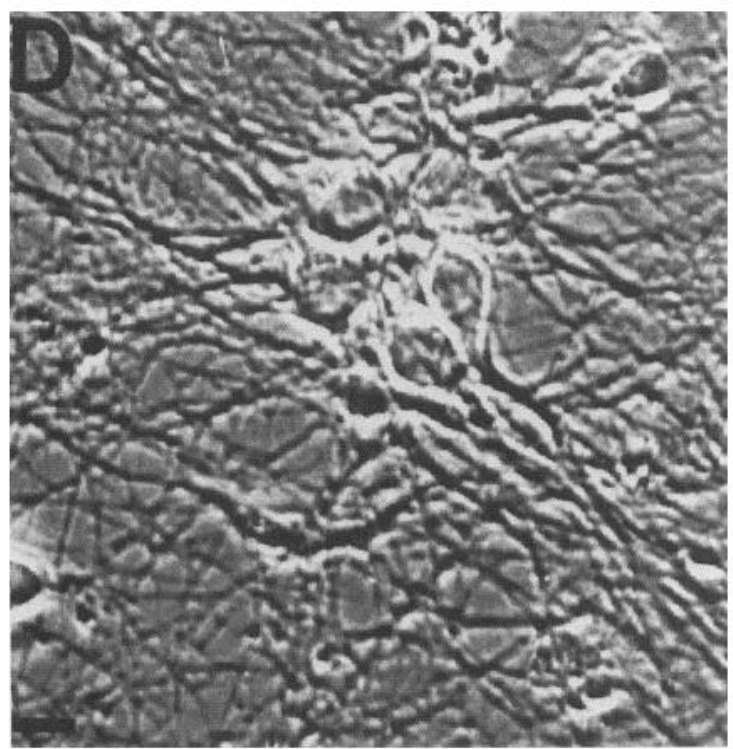

basal changes in fluorescence (Fig. 2) and utilized these conditions throughout this series of experiments.

Exposure to a strong oxidizing agent $\left(\mathrm{H}_{2} \mathrm{O}_{2}, 30 \mathrm{~mm}\right)$ increased fluorescence in nearly all cells examined (Fig. 1A). The fluorescence increase reached a maximum within 4-6 min after application, and was evenly dispersed over most of the cell body. Preliminary experiments suggested that over extended periods of time $(>20 \mathrm{~min})$ fluorescence decreased, consistent with the previously reported leakage of DCF from cells (Royall and Ischiropoulos, 1993). The addition of $100 \mu \mathrm{M}$ glutamate (added together with $10 \mu \mathrm{M}$ glycine throughout the experiments in this study) resulted in a more complex response than observed with $\mathrm{H}_{2} \mathrm{O}_{2}$ (Fig. $1 \mathrm{~B}$ ). Glutamate produced a localized increase in fluorescence typically associated with the margins of the cell body or the base of large processes. This response was observed in 255 out of 439 cells examined (58\%). However, the increase in fluorescence around the periphery was typically accompanied by a striking decrease in fluorescence in the middle of the cell. As a result, the overall change in fluorescence induced by glutamate was a $20 \%$ decrease as compared to starting values (Fig. 2). Although observed consistently, the summation of fluorescence obscures the fact that local increases occur. By comparison, buffer changes alone resulted in a $15 \%$ increase in DCF signal while peroxide more than doubled cellular fluorescence.

To evaluate the relative contributions of NMDA and nonNMDA receptor activation to the observed response we examined the effects of selective receptor agonists and antagonists. When cells were incubated with glutamate $(100 \mu \mathrm{M})$ in the presence of the NMDA receptor blocker dizocilpine (MK801, $1 \mu \mathrm{M}$ ) localized increases in fluorescence were not observed (Fig. 3), and the decrease in cellular fluorescence was somewhat attenuated. CNQX $(50 \mu \mathrm{M})$, the selective non-NMDA receptor antagonist, had no effect on the cellular response to glutamate (Fig. 3). Interestingly, NMDA (100 $\mu \mathrm{M}$ with $10 \mu \mathrm{M}$ glycine) was not as effective as the same concentration of glutamate at producing the local increases in fluorescence, while kainate $(100 \mu \mathrm{M})$ did not increase fluorescence in any of the cells tested (Table 1).

The removal of extracellular $\mathrm{Ca}^{2+}$ also blocked the glutamate-
Figure 2. Mean changes in DCF fluorescence. Fluorescence changes in single cells is expressed as a fraction of the starting fluorescence. Two scans were obtained prior to the addition of $30 \mathrm{mM} \mathrm{H}_{2} \mathrm{O}_{2}$ (triangles) or $100 \mu \mathrm{M}$ glutamate and $10 \mu \mathrm{M}$ glycine (squares), or by the replacement of the chamber solution with buffer alone (circles). The data represents the mean \pm SEM of at least 80 cells in each condition. Where absent error bars were smaller than the symbols. 

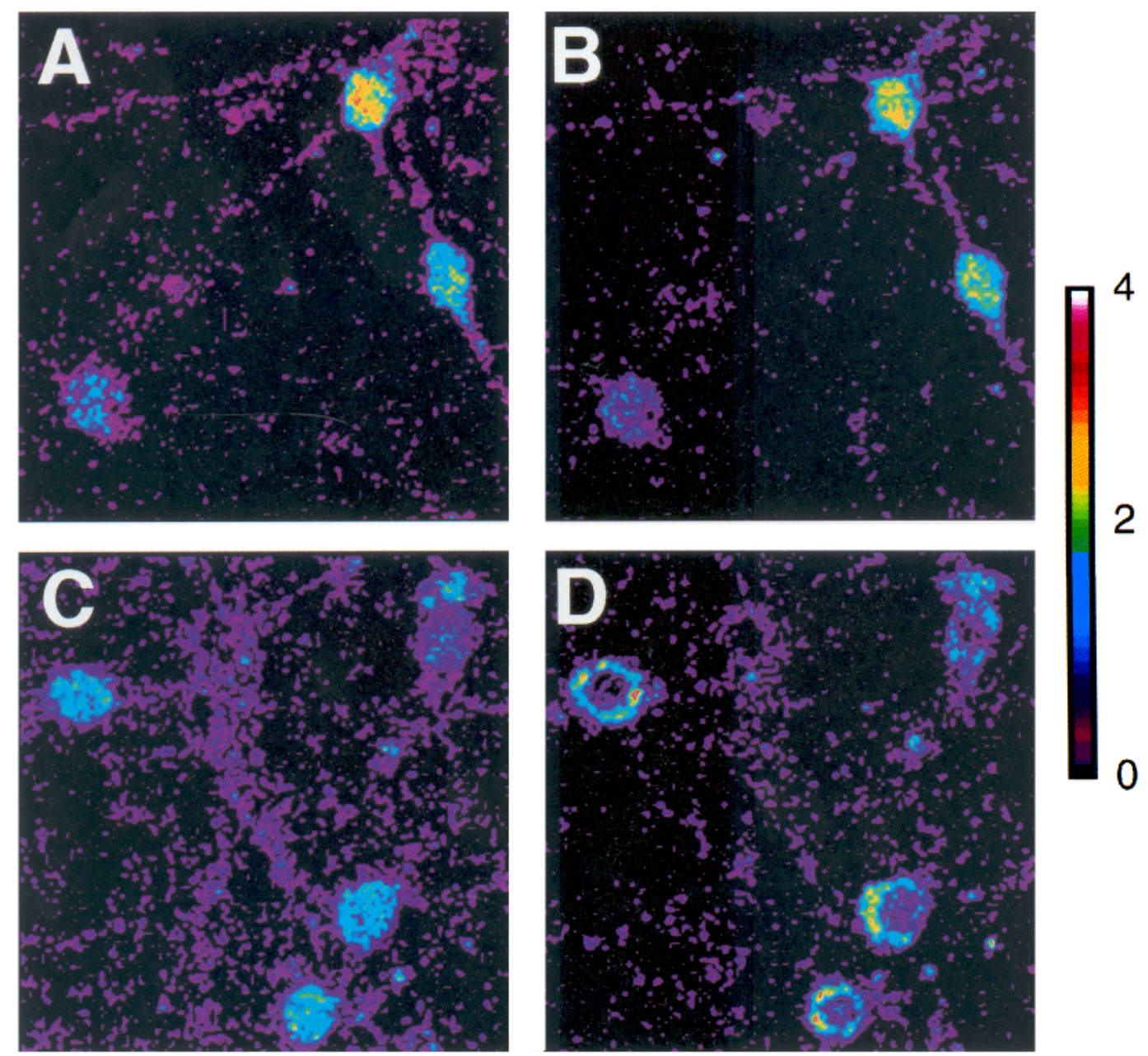

Figure 3. Effects of glutamate receptor antagonists on DCF fluorescence. Responses to $100 \mu \mathrm{M}$ glutamate and $10 \mu \mathrm{M}$ glycine were obtained in the presence of $(A, B) 1 \mu \mathrm{M}$ dizocilpine or $(C, D) 50 \mu \mathrm{M}$ CNQX. In each case the first image was obtained immediately before the addition of the agonists while the second image was obtained six minutes after the addition of agonists. These treatments were repeated in four to six additional coverslips with similar results. Scale bar, $10 \mu \mathrm{m}$.

induced local increases and general decreases in DCF fluorescence (see below and Table 1). The lack of effect on cell fluorescence after this maneuver suggests that the glutamate-induced change in fluorescence was not induced by swelling, because some neuronal swelling was still observed after glutamate addition in $\mathrm{Ca}^{2+}$-free buffer. We also monitored the effects of lower concentrations of glutamate. While local increases in fluorescence were commonly observed following the addition of 100 $\mu \mathrm{M}$ glutamate, the addition of $3 \mu \mathrm{M}$ glutamate with $10 \mu \mathrm{M}$ glycine produced such changes much less often (Table 1). However, $3 \mu \mathrm{M}$ glutamate still effectively decreased cellular fluorescence (not shown).

To further characterize the mechanism of the increased oxidation we monitored the effects of manipulating arachidonic acid metabolism, as NMDA receptor activation stimulates arachidonic acid release in cultured neurons (Dumuis et al., 1988), and produces cyclooxygenase and lipoxygenase-generated superoxide radicals (Lafon-Cazal et al., 1993). Initially, we tested the phospholipase $A_{2}\left(\mathrm{PLA}_{2}\right)$ inhibitor mepacrine in these experiments to block the release of arachidonic acid. However, mepacrine proved unsuitable because it is itself fluorescent under the conditions used for DCF recording. We also found that, at concentrations greater than $5 \mu \mathrm{M}$, mepacrine was an effective inhibitor of ${ }^{3} \mathrm{H}$-dizocilpine binding suggesting that it may also have NMDA receptor antagonist properties in common with structurally related aminoacridines (Albin et al., 1988; Reynolds and Miller, 1988). Next we tested bromophenacylbromide (BPB, $10 \mu \mathrm{M})$ which also inhibits $\mathrm{PLA}_{2}$, and indomethacin $(10 \mu \mathrm{M})$ together with nordihydroguaretic acid (NDGA, $10 \mu \mathrm{M}$ ) to inhibit the cyclooxygenase and lipoxygenase pathways simultaneously. Both of these treatments decreased the fraction of cells that showed local increases in fluorescence in response to glutamate by $30-40 \%$ (Table 1 ).

NMDA receptor activation also has been associated with nitric oxide (NO) production in central neurons (Garthwaite et al., 1988; Bredt and Snyder, 1989). However, we were unable to mimic the effects of glutamate or to increase fluorescence by producing NO with $100 \mu \mathrm{M} \quad S$-nitrosoacetylpenicillamine (SNAP). Likewise we were unable to inhibit the response using the nitric oxide synthase inhibitor nitroarginine $(100 \mu \mathrm{M}$, Table 1). Interestingly, nitroarginine appeared to increase the fraction of cells that responded to glutamate with localized increases in fluorescence.

Mitochondria are a significant intracellular source of ROS. Since the DCF staining pattern observed following glutamate stimulation was similar to that observed with selective mito- 

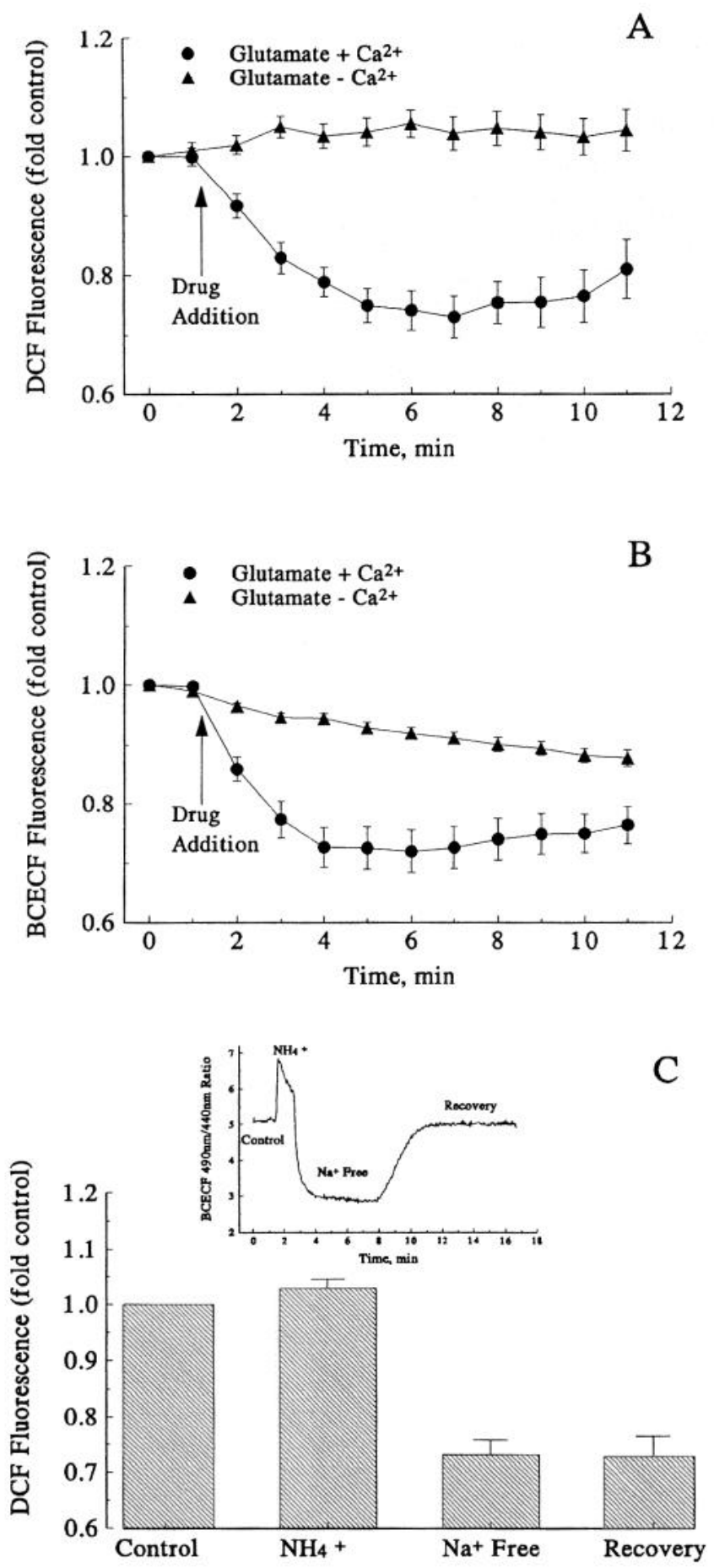

Figure 4. Influence of $\mathrm{pH}$ on DCF fluorescence. $A$, The effects of 100 $\mu \mathrm{M}$ glutamate and $10 \mu \mathrm{M}$ glycine on DCF fluorescence were observed in the presence (circles) or absence (triangles) of extracellular $\mathrm{Ca}^{2+}$ $\left(\mathrm{Ca}^{2+}\right.$-free buffer with $20 \mu \mathrm{M}$ EGTA added). Agonists were added between 1 and 2 min as indicated. These data represent the mean \pm SEM of 35 and 40 cells in the presence and absence of $\mathrm{Ca}^{2+}$, respectively. $B$, The effects of $100 \mu \mathrm{M}$ glutamate and $10 \mu \mathrm{M}$ glycine on BCECF fluorescence were observed in the presence (circles) or absence (triangles) of extracellular $\mathrm{Ca}^{2+}$ Agonists were added between 1 and $2 \mathrm{~min}$ as indicated. $C$, Effects of $\mathrm{pH}$ manipulation on DCF fluorescence. Intracellular $\mathrm{pH}$ was altered in these cells by the addition of $25 \mathrm{mM} \mathrm{NH}_{4} \mathrm{Cl}$ to produce an alkalinization, followed by rinsing in $\mathrm{Na}^{+}$-free buffer ( $\mathrm{Na}^{+}$replaced by $\mathrm{N}$-methyl-D-glucamine). This effectively clamps the $\mathrm{pH}$ in the acid range as indicated by the BCECF data in the inset. The same manipulations result in a small increase in DCF fluorescence in the presence of $\mathrm{NH}_{4} \mathrm{Cl}$ followed by a marked decrease during the $\mathrm{Na}^{+}$- chondrial stains, we sought to test the hypothesis that mitochondria contributed to the response to glutamate. We used the proton ionophore carbonyl cyanide $p$-trifluoromethoxyphenylhydrazone (FCCP, $5 \mu \mathrm{M}$ ) which dissipates the mitochondrial $\mathrm{pH}$ gradient thus inhibiting the production of ATP and also blocking the transport of $\mathrm{Ca}^{2+}$ into the mitochondrial matrix. Preliminary experiments using rhodamine 123 , which accumulates in mitochondria that have a normal membrane potential, indicated that FCCP completely abolished the proton gradient within 1 min of addition at the concentration we used. In these experiments FCCP alone produced a marked decrease in DCF fluorescence but no evidence for any local increases. FCCP completely blocked the oxidation of DCF in response to glutamate (Table 1). The decrease in fluorescence produced by FCCP alone was partially attenuated by the addition of glutamate. It is unlikely that this effect of FCCP was a result of direct quenching of DCF because $75 \mu \mathrm{M}$ FCCP had no effect on DCF fluorescence measured in a cell free system. These observations also were not the result of an FCCP-induced leakage of oxidized dye from the neurons, which we measured by monitoring the concentration of DCF in the extracellular buffer using a spectrofluorimeter (not shown).

We next sought to identify the mechanism underlying the decrease in DCF signal induced by glutamate. DCF, in common with other dyes related to fluorescein, is $\mathrm{pH}$ sensitive and fluorescence is quenched under acidic $\mathrm{pH}$ conditions. We monitored intracellular $\mathrm{pH}$ in response to glutamate using the $\mathrm{pH}$ sensitive dye $2^{\prime}, 7^{\prime}$-bis(2-carboxyethyl)carboxyfluorescein (BCECF). As shown in Figure 4, glutamate produced a decrease in intracellular $\mathrm{pH}$ monitored with BCECF that paralleled the decrease in DCF fluorescence produced by glutamate (Fig. 4A,B). The effect of glutamate on both dyes required the presence of extracellular $\mathrm{Ca}^{2+}$. To further test the hypothesis that DCF fluorescence was $\mathrm{pH}$ sensitive we observed the effects of altering intracellular $\mathrm{pH}$ independent of glutamate receptor activation (Fig. 4C). The addition of $25 \mathrm{mM} \mathrm{NH}_{4} \mathrm{Cl}$ produced a transient intracellular alkalinization. Washing out the $\mathrm{NH}_{4} \mathrm{Cl}$ resulted in an acidic $\mathrm{pH}$ that gradually recovered to baseline. As recovery from this acidification requires $\mathrm{Na}^{+} / \mathrm{H}^{+}$exchange activity, washing out the $\mathrm{NH}_{4} \mathrm{Cl}$ in $\mathrm{Na}^{+}$-free buffer $\left(\mathrm{Na}^{+}\right.$replaced by $\mathrm{N}$-methyl-D-glucamine) results in a stable acidification that lasts as long as the $\mathrm{Na}^{+}$-free buffer is present (Fig. $4 C$, inset) (Schwiening and Boron, 1994). In this series of manipulations $\mathrm{NH}_{4} \mathrm{Cl}$ produced a small increase in DCF fluorescence associated with alkalinization followed by a sustained decrease in dye signal during acidification and recovery (Fig. $4 C$ ), consistent with the hypothesis that the glutamate-induced decrease in DCF fluorescence was due to intracellular acidification.

The BCECF data shown in Figure 4 indicates an overall decrease in dye fluorescence after the application of glutamate, consistent with intracellular acidification. However, by analogy with our results obtained with DCF, it remained possible that NMDA receptor activation resulted in a localized increase in BCECF signal that was masked by a generalized decrease. We performed imaging studies with BCECF to address this point. As shown in Figure 5, we found no evidence for localized increases in BCECF fluorescence following glutamate application, $\leftarrow$

free washout of $\mathrm{NH}_{4} \mathrm{Cl}$. The DCF data represent the mean \pm SEM of 39 cells. In this series of experiments control cells exposed to buffer replacement alone changed by $<7 \%$. 

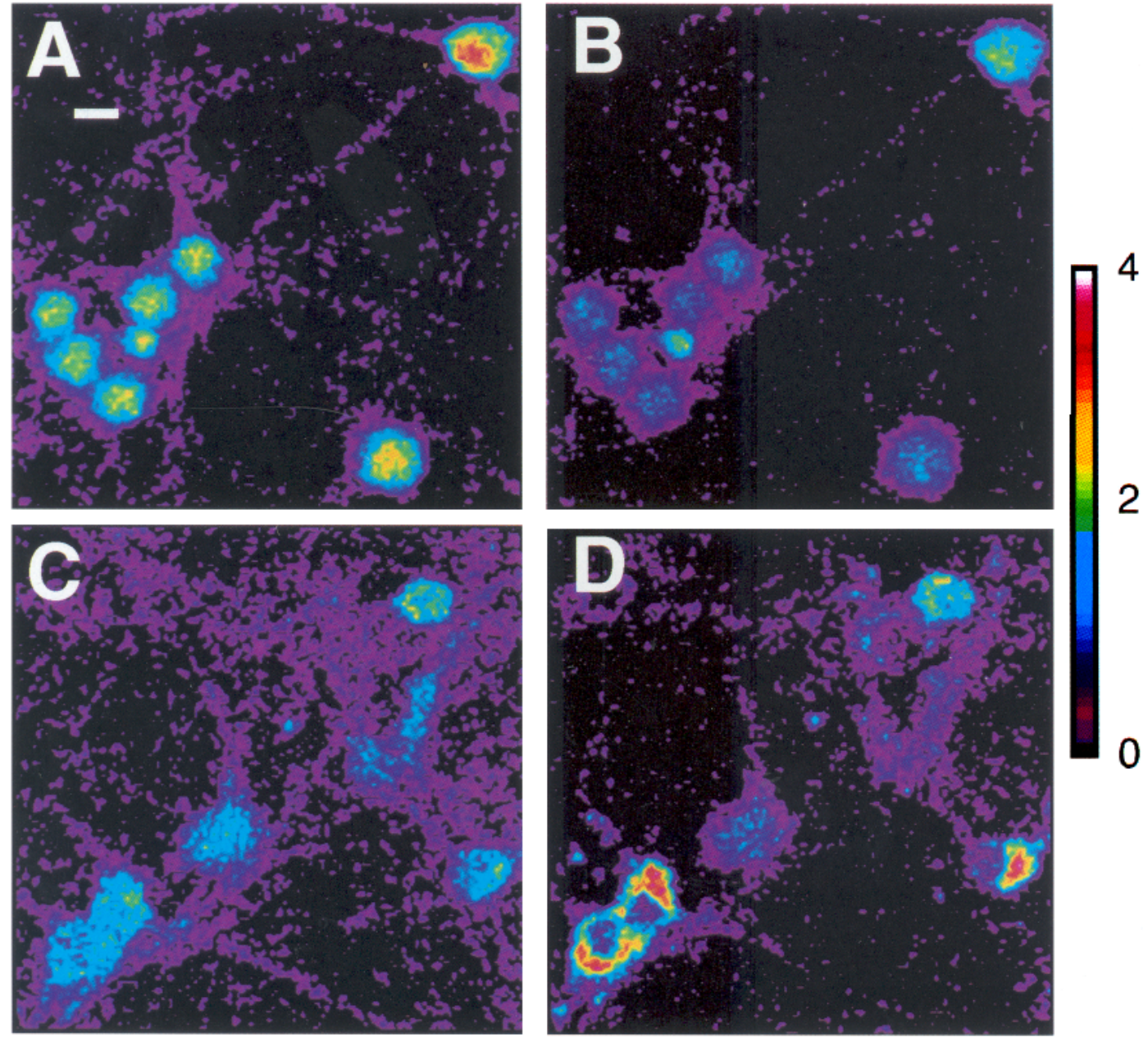

Figure 5. Effects of glutamate on BCECF and DCF fluorescence. $A$ and $B$ were obtained before and 6 min after, respectively, the addition of 100 $\mu \mathrm{M}$ glutamate and $10 \mu \mathrm{M}$ glycine to a field of neurons labeled with BCECF. Glutamate resulted in a generalized decrease in cellular fluorescence with no evidence for localized increases. $C$ and $D$ were obtained before and 6 min after the addition of $100 \mu \mathrm{M}$ glutamate and $10 \mu \mathrm{M}$ glycine to a field of neurons loaded with DCF- $\mathrm{H}_{2}$. As can be seen, several of the neurons responded with the characteristic local increase in DCF signal. These data are representative of two additional coverslips loaded with BCECF and more than 20 additional coverslips loaded with DCF- $\mathrm{H}_{2}$. Scale bar, $20 \mu \mathrm{m}$.

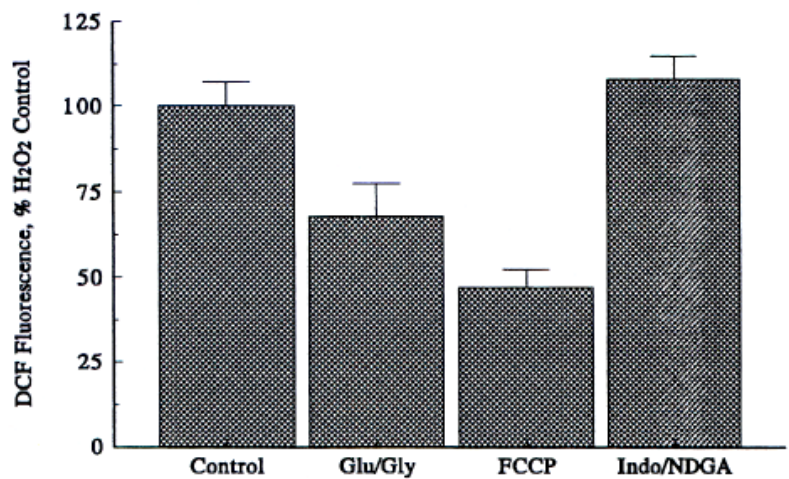

Figure 6. Effects of $\mathrm{H}_{2} \mathrm{O}_{2}$ in drug-pretreated neurons. Neurons were treated with $30 \mathrm{mM} \mathrm{H}_{2} \mathrm{O}_{2}$ two minutes after the addition of buffer (control), $100 \mu \mathrm{M}$ glutamate and $10 \mu \mathrm{M}$ glycine, $5 \mu \mathrm{M}$ FCCP or a combination of $10 \mu \mathrm{M}$ indomethacin and $10 \mu \mathrm{M}$ NDGA. The mean fluorescence change produced by $\mathrm{H}_{2} \mathrm{O}_{2}$ in the presence of each of these agents was normalized to the mean $\mathrm{H}_{2} \mathrm{O}_{2}$-induced change that had occurred six minutes after the addition of $\mathrm{H}_{2} \mathrm{O}_{2}$. These results represent mean data $( \pm$ SEM) obtained from $>35$ neurons each from at least five different coverslips. excluding the possibility that the local changes in DCF signal are a consequence of focal increases in intracellular $\mathrm{pH}$.

It was also possible that the acidification induced by glutamate or FCCP could completely quench the DCF signal. To address this possibility we examined the response of DCF-loaded cells to $\mathrm{H}_{2} \mathrm{O}_{2}$ when added following exposure to glutamate, FCCP or the combination of indomethacin and NDGA (Fig. 6). $\mathrm{H}_{2} \mathrm{O}_{2}$ produced a robust response under each of these conditions, although the response in the presence of glutamate or FCCP was clearly attenuated compared to control values. These data confirm that acidification decreases the response to DCF but indicate that oxidation still produces an observable response even in acidified cells.

\section{Discussion}

In this study we have demonstrated that glutamate receptor activation resulted in the production of ROS in cultured neurons and can be monitored at the level of the single cell using the fluorescent dye DCF. The use of confocal microscopy was a critical factor in obtaining these results because the generation 
of ROS occurs in a very localized fashion. Moreover, this change is accompanied by intracellular acidification, which decreases dye fluorescence and might otherwise obscure the oxidation signal. Indeed, the oxidation signal that we measured was probably attenuated by the superimposition of acidification-induced DCF quenching. Several previous studies have reported the use of DCF to monitor ROS production in neuronal preparations, and have also reported increases in DCF signal in response to glutamate receptor activation as well as $\mathrm{Ca}^{2+}$ entry (Bondy and Lee, 1993; Kane et al., 1993; Oyama et al., 1993, 1994). However, this is the first study to report localization of DCF signals and to characterize the mechanism of glutamateinduced ROS production using this method.

The oxidation response to glutamate seems to be mediated by NMDA receptor activation because it can be completely blocked by relatively low concentrations of dizocilpine, a specific NMDA receptor antagonist. This concentration of dizocilpine also delayed but did not completely block the decrease in fluorescence associated with the glutamate response. CNQX which, in the presence of $10 \mu \mathrm{M}$ glycine, should specifically antagonize non-NMDA receptors did not block the response. The characteristic response to glutamate was also $\mathrm{Ca}^{2+}$ dependent, which is consistent with the involvement of NMDA receptors in this process.

A key advantage of using cultured cells in these studies is the ability to investigate the mechanism of ROS generation, which has proven more difficult to address in in vivo preparations. It previously has been suggested that generation of ROS might occur following the NMDA-induced release of arachidonic acid, which presumably occurs because of the $\mathrm{Ca}^{2+}$-sensitive nature

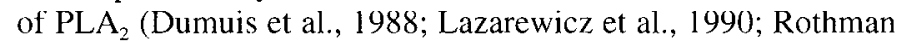
et al., 1993). However, blocking either PLA P $_{2}$ with bromophenacylbromide or the cyclooxygenase/lipoxygenase pathways with indomethacin and NDGA was only partially effective in antagonizing the effect of glutamate, consistent with a partial neuroprotection seen with NDGA in cultured neurons (Rothman et al., 1993). These results support the observation that arachidonic acid is released in response to activation of NMDA receptors, and the possibility that arachidonic acid metabolism is a potential source of ROS in neurons (Dumuis et al., 1988; Lazarewicz et al., 1990; Lafon-Cazal et al., 1993; Rothman et al., 1993). However, these results also imply that other mechanisms of ROS generation may be quantitatively more important. It has also been suggested that the conversion of xanthine dehydrogenase to xanthine oxidase by a $\mathrm{Ca}^{2+}$ activated protease might result in the generation of ROS. However it is not clear that a large amount of the substrate, xanthine, is being generated under the conditions that we used, where hypoxia is not involved (Dykens ct al., 1987).

Our data suggest that mitochondria were the principle source of ROS in these experiments. The proton ionophore FCCP completely blocked the response to glutamate in our preparation. Collapsing the mitochondrial proton gradient would collapse the mitochondrial membrane potential and thereby disrupt the gradient driving $\mathrm{Ca}^{2+}$ into the organelle (Thayer and Miller, 1990; Miller, 1991; Rizzuto et al., 1992). Because mitochondria play an important role in buffering $\mathrm{Ca}^{2+}$ loads imposed by glutamate, FCCP treatment would result in an increased intracellular free $\mathrm{Ca}^{2+}$ level in response to glutamate that can be readily observed using $\mathrm{Ca}^{2+}$-sensitive dyes (White and Reynolds, 1995). The fact that $\left[\mathrm{Ca}^{2+}\right]_{i}$ changes induced by glutamate are higher in the presence of FCCP but that the generation of ROS is blocked strongly suggests that the $\mathrm{Ca}^{2+}$-activated process that occurs does not reside in the cytoplasmic compartment. Likewise, a recent study using isolated brain mitochondria demonstrated that the addition of $\mathrm{Ca}^{2+}$ and ADP resulted in the generation of ROS as a consequence of the uptake of $\mathrm{Ca}^{2+}$ by mitochondria and the subsequent alteration of complex I and complex II activity in the mitochondrial matrix (Dykens, 1994). Thus, evidence exists to suggest that glutamate-induced ROS production occurs as a result of $\mathrm{Ca}^{2+}$ entry into neurons followed by $\mathrm{Ca}^{2+}$ uptake into mitochondria. We have also noted that staining mitochondria with rhodamine 123, a selective mitochondrial marker (Chen et al., 1981), resulted in a cellular staining pattern that was similar to the characteristic DCF staining observed in cells treated with glutamate, thus suggesting a colocalization of the two signals (unpublished observations). Therefore, it is possible that glutamate-induced changes in the electron transport chain result in increased ROS formation.

Some oxidation-sensitive dyes are selectively transported into mitochondria following oxidation, such as dihydrorhodamine (Royall and Ischiropoulos, 1993). This would result in a localization of the dye signal that would not necessarily reflect the site of production of the ROS. However, we found no evidence for relocalization of DCF following peroxide application. Thus, unless there is a specific DCF transport process triggered by glutamate in a $\mathrm{Ca}^{2+}$-dependent fashion, we feel that the local response to glutamate actually reflects the site of ROS production. Although it is generally believed that DCF is found in the cytoplasm it is possible that the oxidation of the dye could occur inside the mitochondria in our experiments. With the spatial resolution attained in these experiments it is difficult to distinguish signal originating within, rather than near, mitochondria.

We are not sure which form of reactive oxygen was generated by glutamate. DCF was originally developed as a tool to measure the generation of hydrogen peroxide, although the selectivity amongst the various reactive species remains unclear (Cathcart et al., 1983; LeBel et al., 1992). NO is probably not involved in this process because concentrations of SNAP that we have previously demonstrated to be effective in mimicking the effects of gaseous NO (Hoyt et al., 1992) did not affect DCF fluorescence. Furthermore nitroarginine, which should block endogenous NO generation did not alter the response to glutamate. This latter point is not surprising as relatively few cells in cortical cultures express nitric oxide synthase (Koh and Choi, 1988). The data shown in Table 1 suggest that the addition of nitroarginine might actually increase the oxidation response to glutamate. In the absence of an opposite response to the addition of SNAP it seems unlikely that this effect is due to inhibition of NO synthesis, and may be a nonspecific effect of the concentration of inhibitor used.

We used $\mathrm{H}_{2} \mathrm{O}_{2}$ as a positive control throughout this series of experiments. Although we used a relatively high concentration $(30 \mathrm{~mm})$ preliminary experiments suggested that responses can be obtained with $\mathrm{H}_{2} \mathrm{O}_{2}$ concentrations as low as 1-3 mM (unpublished observations). It is also possible that substantially lower concentrations of $\mathrm{H}_{2} \mathrm{O}_{2}$ would be effective over longer periods of time. However, the leakage of DCF from neurons makes this possibility hard to assess using the present approach.

There are a number of interesting associations between generation of ROS and excitotoxicity. It is noteworthy that oxidation of DCF was detectable within 2-3 min after application of glutamate. This is within the minimum time period of glutamate application required to produce a lethal stimulus to cells (Choi 
et al., 1987) and implies that ROS generation may be an early and perhaps causative event in excitotoxicity rather than a consequence of cell degeneration. It is interesting that $100 \mu \mathrm{M}$ glutamate was effective at oxidizing DCF whereas $3 \mu \mathrm{M}$ was much less active. We have previously noted that $100 \mu \mathrm{M}$, but not 3 $\mu \mathrm{M}$, glutamate induces excitotoxic cell death in our cultures even though both concentrations of glutamate show similar peak $\left[\mathrm{Ca}^{2+}\right]_{i}$ (Rajdev and Reynolds, 1994), again indicating the disparity between $\left[\mathrm{Ca}^{2+}\right]_{i}$ and ROS generation. However, we have also noted that $100 \mu \mathrm{M}$ glutamate was much more effective at raising $\left[\mathrm{Mg}^{2+}\right]_{i}$ than $3 \mu \mathrm{M}$ glutamate, an observation that we have interpreted to reflect substantial $\mathrm{Ca}^{2+}$ entry (Brocard et al., 1993). It seems possible, therefore, that ROS production is an event associated with $\mathrm{Ca}^{2+}$ overload and subsequent mitochondrial dysfunction, which may be a critical event that dictates the fate of the neuron.

Several possibilities could explain the glutamate-induced decrease in DCF signal. As DCF fluorescence is associated with the oxidized form of the dye it is possible that neurons produce a reducing agent that could convert the dye to a reduced form. However, we were not able to identify any endogenous substance that would reduce DCF to its nonfluorescent form. It is well established that fluorescein-like dyes are $\mathrm{pH}$ sensitive, and decrease fluorescence intensity following acidification. Several recent studies have demonstrated that glutamate produces intracellular acidification in neurons, and that acidification occurs as a result of NMDA receptor activation and $\mathrm{Ca}^{2+}$ entry (Hartley and Dubinsky, 1993; Wang et al., 1993; Irwin et al., 1994). The mechanism inducing the acidification is not clear. However, a recent study showed that glutamate-induced intracellular acidification could be blocked by the injection of ruthenium red which blocks $\mathrm{Ca}^{2+}$ uptake into mitochondria (Wang et al., 1993). This finding suggests a role for mitochondria in the mechanism of acidification, and could occur by $\mathrm{Ca}^{2+}$ competing for $\mathrm{H}^{+}$ transport into mitochondria (Werth and Thayer, 1994). Acidification could also occur as a result of activation of glycolysis, essentially producing lactate acidosis (Wang et al., 1993). At the concentrations used FCCP will also equilibrate $\mathrm{H}^{+}$across the plasma membrane according to the Nernst potential, which should produce acidification at resting membrane potentials (Wang et al., 1993). Cell depolarization would partially dissipate the gradient for $\mathrm{H}^{+}$accumulation, resulting in less acidification. Our observation that glutamate mitigates the ability of FCCP to decrease DCF fluorescence is consistent with this scenario and supports the contention that DCF measures intracellular $\mathrm{pH}$ as well as oxidation. It was possible that the increase in DCF signal that we have attributed to dye oxidation was, in fact, due to localized increases in $\mathrm{pH}$. This seems unlikely to be the case, because BCECF imaging did not reveal any pattern of localized increases in fluorescence signal in response to glutamate addition, and is clearly distinct from the effects of glutamate on DCF-H $\mathrm{H}_{2}$ loaded cells (Fig. 5). However, it is important to note that acidification was not able to completely block the response of DCF to oxidation, such that the lack of a response could not be attributed to dye quenching alone.

\section{References}

Albin RL, Young AB. Penney JB (1988) Tetrahydro-9-aminoacridine (THA) interacts with the phencyclidine (PCP) receptor site. Neurosci Lett 88:303-307.

Beal MF (1992) Does impairment of energy metabolism result in excitotoxic neuronal death in neurodegenerative illness? Ann Neurol 31:119-130.
Benveniste H (1991) The excitotoxin hypothesis in relation to ecrebral ischemia. Cerebrovasc Brain Metab Rev 3:213-245.

Bondy SC, Lee DK (1993) Oxidative stress induced by glutamate receptor agonists. Brain Res 610:229-233.

Bredt DS, Snyder SH (1989) Nitric oxide mediates glutamate-linked enhancement of cGMP levels in the cerebellum. Proc Natl Acad Sci USA 86:9030-9033.

Brocard JB, Rajdev S, Reynolds IJ (1993) Glutamate induced increases in intracellular free $\mathrm{Mg}^{2+}$ in cultured cortical neurons. Neuron 11: 751-757.

Cathcart R, Schwiers E, Ames BN (1983) Detection of picomole levels of hydroperoxides using a fluorescent dichlorofluorescein assay. Anal Biochem 134:111-116.

Chen LB, Summerhayes IC, Johnson LV, Walsh ML, Bernal SD and Lampidis TJ (1981) Probing mitochondria in living cells with rhodamine 123. Cold Spring Harbor Symp Quant Biol 46:141-155.

Choi DW (1987) Ionic dependence of glutamate neurotoxicity. J Neurosci $\%: 369-3 / 9$

Choi DW (1988) Glutamate neurotoxicity and diseases of the nervous system. Neuron 1:623-634.

Choi DW (1990) Cerebral hypoxia: some new approaches and unanswered questions. J Neurosci 10:2493-2501.

Choi DW, Maulucci-Gedde M, Kriegstein AR (1987) Glutamate neurotoxicity in cortical cell culture. J Neurosci 7:357-368.

Coyle JT, Puttfarcken P (1993) Oxidative stress, glutamate, and neurodegenerative disorders. Science 262:689-695.

Dawson VL, Dawson TM, London ED, Bredt DS, Snyder SH (1991) Nitric oxide mediates glutamate neurotoxicity in primary cortical cultures. Proc Natl Acad Sci USA 88:6368-6371.

Dumuis A, Sebben M, Haynes L, Pin J-P, Bockaert J (1988) NMDA receptors activate the arachidonic acid cascade in striatal neurons. Nature 336:68-70.

Dykens JA (1994) Isolated cerebral and cerebellar mitochondria produce free radicals when exposed to elevated $\mathrm{Ca}^{2+}$ and $\mathrm{Na}^{+}$: implications for neurodegeneration. J Neurochem 63:584-591.

Dykens JA, Stern A, Trenkner E (1987) Mechanism of kainate toxicity to cerebellar neurons in vitro is analogous to reperfusion tissue injury. J Neurochem 49:1222-1228.

Faden AI, Demediuk P, Panter SS, Vink R (1989) The role of excitatory anino acids and NMDA receptors in trauntatic brain injury. Science 244:798-800.

Frandsen A, Schousboe A (1993) Excitatory amino acid-mediated cytotoxicity and calcium homeostasis in cultured neurons. J Neurochem 60:1202-1211.

Garthwaite J, Charles SL, Chess-Williams R (1988) Endothelium derived relaxing factor release on activation of NMDA receptors suggests role as intercellular messenger in brain. Nature 336:385-388.

Haddad GG, Jiang C (1993) O2 deprivation in the central nervous system: on mechanisms of neuronal response, differential sensitivity and injury. Prog Neurobiol 40:277-318.

Hall ED, Braughler JM (1989) Central nervous system trauma and stroke. II. Physiological and pharmacological evidence for involvement of oxygen radicals and lipid peroxidation. Free Radical Biol Med 6:303-313.

Halliwell B (1992) Reactive oxygen species in the central nervous system. J Neurochem 59:1609-1623.

Hartley Z, Dubinsky JM (1993) Changes in intracellular pH associated with glutamate excitotoxicity. J Neurosci 13:4690-4699.

Hoyt KR, Tang L-H, Aizenman E, Reynolds IJ (1992) Nitric oxide modulates NMDA-induced increases in intracellular $\mathrm{Ca}^{2+}$ in cultured rat forebrain neurons. Brain Res 592:310-316.

Irwin RP, Lin S Z, Long RT, Paul SM (1994) $N$ Methyl D aspartate induces a rapid, reversible and calcium dependent intracellular acidosis in cultured fetal rat hippocampal neurons. J Neurosci 14:13521357.

Kane DJ, Sarafian TA, Anton R, Hahn H, Gralla EB, Valentine JS, Örd T, Bredesen DE (1993) Bcl-2 inhibition of neural death: decreased generation of reactive oxygen species. Science 262:1274-1277.

Koh JY, Choi DW (1988) Vulnerability of cultured cortical neurons to damage by excitotoxins: differential susceptibility of neurons containing NADPH-diaphorase. J Neurosci 8:2153-2163.

Lafon-Cazal M, Pietri S, Culcasi M, Bockaert J (1993) NMDA-dependent superoxide production and neurotoxicity. Nature 364:535-537.

Lazarewicz JW, Wroblewski JT, Costa E (1990) N-Methyl-D-aspartatesensitive glutamate receptors induce calcium-mediated arachidonic 
acid release in primary cultures of cerebellar gramule cells. J Neurochem 55:1875-1881.

LeBel CP, Ischiropoulos H, Bondy SC (1992) Evaluation of the probe $2^{\prime}, 7^{\prime}$-dichlorofluorescein as an indicator of reactive oxygen species formation and oxidative stress. Chem Res Toxicol 5:227-231.

Miller RJ (1991) The control of neuronal $\mathrm{Ca}^{2+}$ homeostasis. Prog Neurobiol 37:255-285.

Monyer H, Hartley DM, Choi DW (1990) 21-aminosteroids attenuate excitotoxic neuronal injury in cortical cell cultures. Neuron 5:121126.

Oyama Y, Hayashi A, Ueha T, Chikahisa L, Furukawa K (1993) Fluorescent estimation on the effect of $\mathrm{Ca}^{2+}$ antagonists on the oxidative metabolism in dissociated mammalian brain neurons. Brain Res 610: 172-175.

Oyama Y, Hayashi A, Ueha T, Maekawa K (1994) Characterization of $2^{\prime}, 7^{\prime}$-dichlorofluorescein fluorescence in dissociated mammalian brain neurons: estimation on intracellular content of hydrogen peroxide. Brain Res 635:113-117.

Rajdev S, Reynolds IJ (1994) Glutamate-induced intracellular calcium changes and neurotoxicity in vitro: effects of chemical ischemia. Neuroscience, in press.

Reynolds IJ, Aizenman E (1992) Pentamidine is an $N$-methyl-D-aspartate receptor antagonist and is neuroprotective in vitro. $\mathbf{J}$ Neurosci 12:970-975

Reynolds IJ, Miller RJ (1988) [ $\left.{ }^{3} \mathrm{H}\right]$ MK801 binding to the $N$-methylD-aspartate receptor reveals drug interactions with the zinc and magnesium sites. J Pharmacol Exp Ther 247:1025-1031.

Rizzuto R, Simpson AWM, Brini M, Pozzan T (1992) Rapid changes of mitochondrial $\mathrm{Ca}^{2+}$ revealed by specifically targeted recombinant aequorin. Nature 358:325-327.

Rothman SM (1985) The neurotoxicity of excitatory amino acids is produced by passive chloride influx. J Neurosci 5:1483-1489.
Rothman SM, Olney JW (1987) Excitotoxicity and the NMDA receptor. Trends Neurosci 10:299-302.

Rothman SM, Thurston JH, Hauhart RE (1987) Delayed neurotoxicity of excitatory amino acids in vitro. Neuroscience 22:471-480.

Rothman SM, Yamada KA, Lancaster N (1993) Nordihydroguaiaretic acid attenuates NMDA neurotoxicity-action beyond the receptor Neuropharmacology 32:1279-1288

Royall JA and Ischiropoulos H (1993) Evaluation of 2',7'-dichlorofluorescin and dihydrorhodamine 123 as fluorescent probes for intracellular $\mathrm{H}_{2} \mathrm{O}_{2}$ in cultured endothelial cells. Arch Biochem Biophys 302:348-355.

Schwiening CJ, Boron WF (1994) Regulation of intracellular $\mathrm{pH}$ in pyramidal neurones from the rat hippocampus by $\mathrm{Na}^{+}$-dependent $\mathrm{Cl}^{-}-\mathrm{HCO}_{3}{ }^{-}$exchange. J Physiol (Lond) 475:59-67.

Siesjo BK, Wieloch T (1985) Cerebral metabolism in ischemia: neurochemical basis for therapy. Br J Anaesth 57:47-62.

Thayer SA, Miller RJ (1990) Regulation of the intracellular free calcium concentration in single rat dorsal root ganglion neurones in vitro. J Physiol (Lond) 425:85-115.

Tombaugh GC, Sapolsky RM (1993) Evolving concepts about the role of acidosis in ischemic neuropathology. J Neurochem 61:793-803.

Wang GJ, Randall RD, Thayer SA (1993) Glutamate-induced intracellular $\mathrm{pH}$ changes in hippocampal neurons demonstrate altered energy metabolism resulting from $\mathrm{Ca}^{2+}$ and $\mathrm{Na}^{+}$loads. Soc Neurosci Abstr 19:1770.

Werth JL, Thayer SA (1994) Mitochondria buffer physiological calcium loads in cultured rat dorsal root ganglion neurons. J Neurosci 14 348-356.

White RJ, Reynolds IJ (1995) Mitochondria and $\mathrm{Na}^{+} / \mathrm{Ca}^{2+}$ exchange buffer glutamate-induced calcium loads in cultured cortical neurons. J Neurosci, in press.

Wieloch T (1985) Neurochemical correlates of selective neuronal vulnerability. Prog Brain Res 63:69-85. 